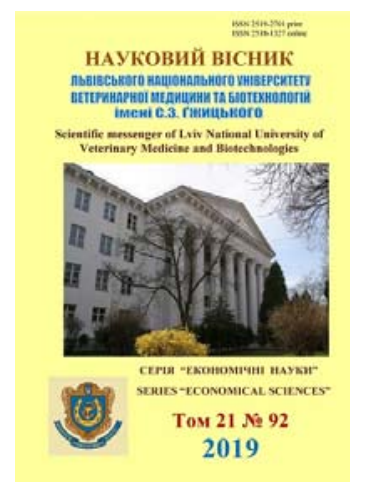

\section{Науковий вісник Дьвівського національного університету ветеринарної медицини та біотехнологій імені С.3. Гжицького.}

\author{
Серія: Економічні науки
}

\author{
Scientific Messenger of Lviv National University \\ of Veterinary Medicine and Biotechnologies. \\ Series: Economical Sciences
}

UDC 631.3: 681.3

\title{
Algorithm of rations calculation of animals feeding and areas of green crops sowing
}

B. Kozij, O. Stepanjuk

Stepan Gzhytskyi National University of Veterinary Medicine and Biotechnologies Lviv, Ukraine

Article info

Received 21.01.2019

Received in revised form 25.02.2019

Accepted 26.02.2019

Stepan Gzhytskyi National University of Veterinary Medicine and Biotechnologies Lviv,

Pekarska Str., 50, Lviv, 79010, Ukraine.

Tel.: +38-097-492-09-70

E-mail:kitm@ukr.net
Kozij, B., \& Stepanjuk, O. (2019). Algorithm of rations calculation of animals feeding and areas of green crops sowing. Scientific Messenger of Lviv National University of Veterinary Medicine and Biotechnologies. Series: Economical Sciences, 21(92), 55-59. doi: 10.32718/nvlvet-e9209

The most important factor of realization of genetic potential of animals is a valuable feeding. Considerable attention is today spared to this problem and are conducted many researches of the rationssent to perfection of structure taking into account the physiological features of animals digestion. The process of rations calculation of animals feeding includes the need in public work with plenty of certificate information: by tabular data about content of nutritives, macro- and microelements, vitamins in each type of feed, by the results of lab tests of forage, requirements in the nutritives of animals of different sexual-age-old groups. Work is considerably simplified, if all this information is kept in memory of computer as a corresponding base. A standard database contains certificate information about the content of nutritives, macro- and microelements, vitamins, and other in every type of feed in accordance with average data for a corresponding region or zone of agriculture. Such information is conditionallypermanent, as properties of soil and natural and climatic conditions for a concrete region change very slowly. At the rations calculation of agricultural animals feeding and poultry bird it is necessary to have operative information about the real content in corresponding forage all those substances after that there will be a balanced ration. Depending on weather conditions the quality of the used seed, amount and added fertilizer conditions and expiration of forage date the real content of nutritives in every feed candiffer from a standard for this region. So before of calculations, it is necessary to amend changes in the table of database that will be directly used in calculations. With the aim of maintenance of standard information such calculations should be performed with the use of some copy of standard database in which should make such changes. An algorithm is offered for realization of calculation of rations of feeding of agricultural animals together with determination of areas of sowing of corresponding greencrops on the basis of the worked out mathematical model but methodology of realization of this algorithm by facilities of tabular processor of Excel.

Key words: mathematical model, algorithm of calculations, ration of animals feeding, area of sowing of green crops, feed data base.

\section{Алгоритм обчислення раціонів годівлі тварин та площ посіву кормових культур}

\author{
Б.I. Козій, О.І. Степанюк
}

Львівський національний університет ветеринарної медицини та біотехнологій імені С.3. Гжиџького, м. Львів, Україна

Найважливішим фактором реалізації генетичного потенціалу тварин є повноцінне живлення. Цій проблемі сьогодні приділяється значна увага, і проводиться багато досліджень, спрямованих на вдосконалення структури рачіонів з урахуванням фізіологічних особливостей травлення тварин. Прочес обчислення рачіонів годівлі тварин передбачає потребу в громіздкій роботі з великою кількістю довідкової інформації: табличними даними про вміст поживних речовин, макро- та мікроелементів, вітамінів у кожному виді корму, результатами лабораторних аналізів кормів, потребами в поживних речовинах тварин різних статево- 
вікових груп. Робота значно спрощується, якщз вся ия інформація зберігається в пам'яті комп'ютера у вигляді відповідної бази даних. Стандартна база даних містить довідкову інформацію про вміст поживних речовин, макро- та мікроелементів, вітамінів, та ін. в кожному виді корму відповідно до середньостатистичних даних для певного регіону чи зони землеробства. Така інформація є умовно-постійною, оскільки властивості трунту та природно-кліматичні умови для конкретного регіону змінюються дуже повільно. При обчисленні раціонів годівлі сільськогосподарських тварин та птиці необхідно мати оперативну інформацію про реальний вміст у відповідних кормах усіх тих речовин, за якими буде балансуватися раціон. Залежно від погодних умов, якості використаного насіння, кількості та якості внесених добрив, умов та терміну зберігання кормів реальний вміст поживних речовин в кожному кормі може відрізнятися від стандарту для даного регіону. Тому перед виконанням обчислень необхідно внести відповідні зміни в таблиию бази даних, яка буде безпосередньо використовуватися в розрахунках. 3 метою збереження стандартної інформачії такі обчислення слід виконувати з використанням деякої копї стандартної бази даних, в яку слід внести відповідні зміни. Пропонується алгоритм для реалізачї обчислення рачіонів годівлі сільськогосподарських тварин разом з визначенням площ, посіву відповідних кормових культур на основі розробленої математичної моделі та методика реалізації иього алгоритму засобами табличного прочесора Exсеl.

Ключові слова: математична модель, алгоритм обчислень, раціон годівлі тварин, площі посіву кормових культур, база даних кормів.

Процес розрахунку раціону годівлі тварин чи птиці навіть для досвідчених спеціалістів тваринництва $\epsilon$ достатньо трудомістким оскільки вимагає значних затрат часу на багаторазове виконання великої кількості обчислень. Звичайно, об’єм обчислювальної роботи зростає пропорційно до збільшення кількості параметрів, за якими необхідно балансувати цей раціон. Бажаною в цій ситуації $\epsilon$, очевидно, можливість автоматизувати весь процес рутинної обчислювальної роботи перерахунку відповідних таблиць (Kozii et al., 2001).

Пропонується алгоритм для реалізації обчислення раціонів годівлі сільськогосподарських тварин разом 3 визначенням площ посіву відповідних кормових культур та методика реалізації цього алгоритму засобами табличного процесора Excel. Математична модель задачі має такий вигляд.

Позначимо кількість статево-вікових груп тварин деякого стада, для яких виконуються обчислення, через $G$. Тоді номер кожної трупи: $K=1,2, \ldots, G$.

Якщо позначити кількість видів кормів в раціонах груп тварин через $N$, а кількість поживних речовин, за якими балансуються раціони годівлі через $M$, то номер кожного виду корму: $i=1,2, \ldots, N$, а номер речовини: $j=1,2, \ldots, M$.

Нехай позначимо:

$x_{i K}-$ кількість i - го виду корму в раціоні $K-$ ої групи тварин;

$a_{i j}-$ вміст $j$ - ої поживної речовини в 1 кг $i$ - го виду корму;

$S_{j K}$ - сумарна кількість $j$ - ої поживної речовини в раціоні $K$ - ої групи тварин;

$S_{i K Z}$ - рекомендований вміст $j$ - ої поживної речовини в раціоні $K$ - ої групи тварин;

$d_{i K}-$ допустиме відхилення вмісту $j$ - ої поживної речовини в раціоні $K$ - ої групи тварин від рекомендованого значення.

Тоді:

$$
S_{j K}=\sum a_{i j} * x_{i K} \quad(i=1,2, \ldots N) .
$$

У випадку, коли

$$
\left|S_{j K}-S_{i K Z}\right|<d_{i K}
$$

необхідно здійснити перерахунок вмісту кормів в обчислюваному раціоні.

Сумарна потреба $\mathrm{X}_{i S} \quad$ в $i$ - тому виді корму для годівлі усіх тварин стада рівна:

$$
X_{i S}=\sum x_{i K} * t_{K} * L_{K} \quad(K=1,2, \ldots, G),
$$

де $L_{K}-$ кількість тварин $K$ - ої групи;
$t_{K}-$ кількість днів годівлі тварин $K$ - ої групи протягом року.

Тоді площі посіву $P_{i}$ кормових культур, які будуть використовуватися для виготовлення кормів, можна обчислити таким чином:

$$
P_{i}=X_{i S} * R_{i} / V_{\mathrm{i}} \quad(i=1,2, \ldots, N),
$$

де $V_{i}$ - вихід корму з урожаю сільськогосподарської культури, яка використовується для виготовлення $i$ - того виду корму;

$R_{i}$ - коефіцієнт ризику, який враховує можливі несприятливі погодні умови:

$$
R_{i} \geq 1 .
$$

Алгоритм, який реалізує запропоновану математичну модель, наведено на рис. 1.

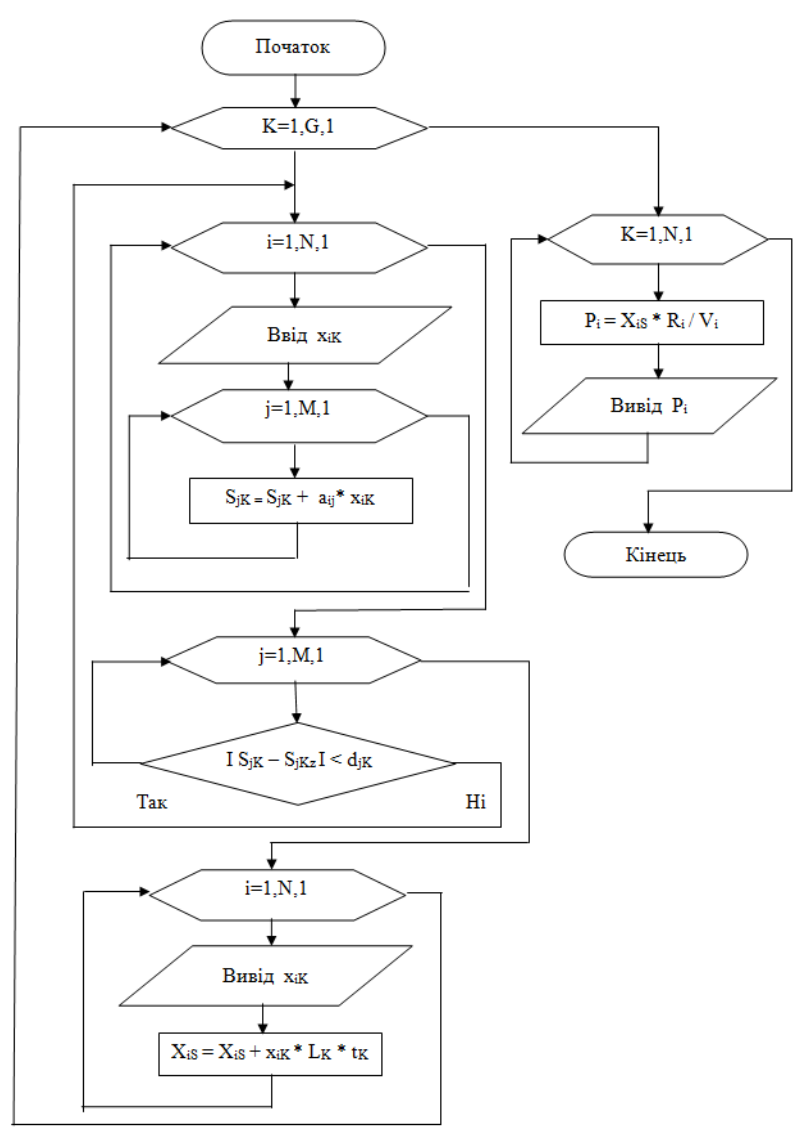

Рис. 1. Алгоритм обчислення раціонів та посівних площ 
Пропонується ряд автоматизованих систем обчислення раціонів годівлі, відповідно свиней, великої рогатої худоби та птиці, що розроблені засобами табличного процесора Excel пакету прикладних програм Microsoft Office. Всі ці системи мають подібну структуру. Кожна з них оформлена у вигляді книги таблиць 3 відповідною кількістю сторінок. Розглянемо загальну структуру такої системи та принцип розрахунку раціону на прикладі автоматизованої системи обчислення раціону годівлі свиней (Tsereniuk et al., 2015).

Книга таблиць цієї системи містить кілька сторінок. Перша сторінка $є$ інформаційною і містить загальний опис системи. Вона призначена для ознайомлення користувача зі структурою системи та іï можливостями. Тут викладено також послідовність роботи $з$ системою.

На другій сторінці міститься таблиця бази даних про корми, що можуть використовуватися для годівлі свиней. Для кожного корму в базі зберігається інфор- мація про вміст в 1 кг поживних речовин макро- та мікроелементів. В стартовому варіанті бази даних характеристики кормів відповідають стандарту для західного регіону України, зокрема для зони Полісся (табл. 1). При роботі з системою базу даних можна актуалізувати, вносячи в неї для кожного корму відповідні характеристики, що одержані в результаті лабораторних аналізів вмісту в кормі поживних речовин. При роботі системи інформація $з$ другої сторінки використовується для автоматичного підрахунку вмісту в раціоні речовин, за якими балансується раціон та вартість добового раціону годівлі свиней.

На третій сторінці міститься таблиця бази даних про норми годівлі різних статево-вікових груп свиней. Кожна стрічка таблиці відповідає одній з таких груп. Якщо в подальшому, при роботі з системою, виявиться, що користувач має потребу в обчисленні раціонів годівлі для інших груп свиней, він може доповнити базу, сформувавши відповідні нові стрічки.

\section{Таблиця 1}

База даних для обчислення раціону годівлі свиней

\begin{tabular}{|c|c|c|c|c|c|c|c|c|c|}
\hline \multicolumn{10}{|c|}{ Вміст поживних речовин в 1 кг корму } \\
\hline Назва корму & $\begin{array}{l}\text { Кормові } \\
\text { одиниці }\end{array}$ & $\begin{array}{c}\text { Обмінна } \\
\text { енергія }\end{array}$ & $\begin{array}{c}\text { Суха } \\
\text { речовина }\end{array}$ & $\begin{array}{c}\text { Сирий } \\
\text { протеїн }\end{array}$ & $\begin{array}{l}\text { Перетр. } \\
\text { протеїн }\end{array}$ & $\begin{array}{c}\text { Сира } \\
\text { клітков. }\end{array}$ & Лізин & Кальцій & фосфор \\
\hline & кГ & МДж & $\Gamma$ & $\Gamma$ & $\Gamma$ & $\Gamma$ & $\Gamma$ & $\Gamma$ & $\Gamma$ \\
\hline Горох & 1,18 & 13,06 & 850 & 218 & 192 & 54 & 14,2 & 2 & 4,3 \\
\hline Овес & 1 & 10,78 & 850 & 108 & 79 & 97 & 3,6 & 1,5 & 3,4 \\
\hline Пшениця & 1,28 & 13,56 & 850 & 133 & 106 & 17 & 3 & 0,8 & 3,6 \\
\hline Ячмінь & 1,15 & 12,7 & 850 & 113 & 85 & 49 & 4,1 & 2 & 3,9 \\
\hline Кукурудза & 1,33 & 13,67 & 850 & 103 & 73 & 38 & 2,1 & 0,5 & 5,2 \\
\hline Висівки пшеничні & 0,75 & 9,28 & 850 & 151 & 97 & 88 & 5,4 & 2 & 9,6 \\
\hline Макуха соняшник & 1,08 & 12,25 & 900 & 405 & 324 & 129 & 13,4 & 5,9 & 12,9 \\
\hline Вика & 0,17 & 1,99 & 220 & 49 & 33 & 59 & 2,2 & 2,4 & 0,8 \\
\hline Конюшина & 0,2 & 2,13 & 235 & 39 & 27 & 61 & 1,5 & 3,7 & 0,6 \\
\hline Люпин & 0,19 & 2,25 & 200 & 43 & 31 & 57 & 1,9 & 1,9 & 0,5 \\
\hline Люцерна & 0,22 & 1,99 & 250 & 50 & 38 & 68 & 1,9 & 4,5 & 0,7 \\
\hline Картопля сира & 0,3 & 3,19 & 220 & 18 & 10 & 8 & 1 & 0,2 & 0,5 \\
\hline Картопля варена & 0,32 & 3,34 & 230 & 18 & 11 & 8 & 1 & 0,1 & 0,5 \\
\hline Буряк кормовий & 0,12 & 1,74 & 120 & 13 & 9 & 9 & 0,4 & 0,4 & 0,5 \\
\hline Морква & 0,14 & 1,74 & 120 & 12 & 8 & 11 & 0,5 & 0,9 & 0,6 \\
\hline Жом свіжий & 0,12 & 1,74 & 112 & 12 & 6 & 33 & 1,2 & 1,5 & 0,14 \\
\hline Дріжджі сухі & 1,19 & 14,69 & 900 & 455 & 419 & 2 & 30,9 & 3,85 & 14,9 \\
\hline Молоко цільне & 0,3 & 2,88 & 130 & 35 & 33 & 0 & 2,8 & 1,3 & 1,2 \\
\hline Відвійки свіжі & 0,13 & 1,51 & 90 & 37 & 35 & 0 & 2,9 & 1,4 & 1 \\
\hline Сироватка свіжа & 0,13 & 1,1 & 59 & 10 & 9 & 0 & 0,6 & 0,4 & 0,5 \\
\hline Мука м'ясо-кістк. & 1,04 & 11,5 & 900 & 401 & 341 & 0 & 21,7 & 143 & 74 \\
\hline
\end{tabular}

Четверта сторінка містить розрахункову таблицю, за допомогою якої формується раціон годівлі для тварин відповідної статево-вікової групи (табл. 2). Формування раціону здійснюється шляхом підбору вмісту в ньому певної кількості відповідних кормів за алгоритмом, наведеним на рис. 1 .

3 третьої сторінки в стрічку “Норми годівлі” розрахункової таблиці треба копіювати стрічку, яка міс- тить норми годівлі для відповідної статево-вікової групи свиней.

Результати обчислень вносяться у відповідні клітини рядка "Разом” розрахункової таблиці. Далі система обчислює відхилення вмісту $j$-ї поживної речовини від заданої норми і вносить їх у стрічку "Різниця”. 
Таблиця 2

Таблиця для виконання обчислень

\begin{tabular}{|c|c|c|c|c|c|c|c|c|c|c|c|}
\hline Назва корму & Вміст & Вміст & $\begin{array}{l}\text { Корм } \\
\text { один. }\end{array}$ & $\begin{array}{l}\text { Обмін. } \\
\text { енергія }\end{array}$ & $\begin{array}{c}\text { Суха } \\
\text { речов. }\end{array}$ & $\begin{array}{c}\text { Сирий } \\
\text { протеїн }\end{array}$ & $\begin{array}{l}\text { Перетр. } \\
\text { протеїн }\end{array}$ & $\begin{array}{l}\text { Сира } \\
\text { клітк. }\end{array}$ & Лізин & Кальцій & Фосфор \\
\hline & \% к.о. & кГ & кГ & МДж & $\Gamma$ & $\Gamma$ & $\Gamma$ & $\Gamma$ & $\Gamma$ & $\Gamma$ & $\Gamma$ \\
\hline Горох & 15 & 0,28 & 0,33 & 3,652 & 237,71 & 60,966 & 53,695 & 15,1 & 4 & 0,559 & 1,203 \\
\hline Овес & 0 & 0 & 0 & 0 & 0 & 0 & 0 & 0 & 0 & 0 & 0 \\
\hline Пшениця & 35 & 0,602 & 0,77 & 8,157 & 511,33 & 80,008 & 63,766 & 10,23 & 1,8 & 0,481 & 2,166 \\
\hline Ячмінь & 45 & 0,861 & 0,99 & 10,93 & 731,74 & 97,278 & 73,174 & 42,18 & 3,5 & 1,722 & 3,357 \\
\hline Кукурудза & 0 & 0 & 0 & 0 & 0 & 0 & 0 & 0 & 0 & 0 & 0 \\
\hline Висівки пш. & 0 & 0 & 0 & 0 & 0 & 0 & 0 & 0 & 0 & 0 & 0 \\
\hline Макуха сон. & 5 & 0,102 & 0,11 & 1,248 & 91,667 & 41,25 & 33 & 13,14 & 1,4 & 0,601 & 1,314 \\
\hline Вика & 0 & 0 & 0 & 0 & 0 & 0 & 0 & 0 & 0 & 0 & 0 \\
\hline Конюшина & 0 & 0 & 0 & 0 & 0 & 0 & 0 & 0 & 0 & 0 & 0 \\
\hline Люпин & 0 & 0 & 0 & 0 & 0 & 0 & 0 & 0 & 0 & 0 & 0 \\
\hline Люцерна & 0 & 0 & 0 & 0 & 0 & 0 & 0 & 0 & 0 & 0 & 0 \\
\hline Картопля ср. & 5 & 0,367 & 0,11 & 1,17 & 80,667 & 6,6 & 3,6667 & 2,933 & 0,4 & 0,073 & 0,183 \\
\hline Картопля вр. & 0 & 0 & 0 & 0 & 0 & 0 & 0 & 0 & 0 & 0 & 0 \\
\hline Буряк корм. & 0 & 0 & 0 & 0 & 0 & 0 & 0 & 0 & 0 & 0 & 0 \\
\hline Морква & 0 & 0 & 0 & 0 & 0 & 0 & 0 & 0 & 0 & 0 & 0 \\
\hline Жом свіжий & 0 & 0 & 0 & 0 & 0 & 0 & 0 & 0 & 0 & 0 & 0 \\
\hline Дріжджі сух. & 0 & 0 & 0 & 0 & 0 & 0 & 0 & 0 & 0 & 0 & 0 \\
\hline Молоко ціл. & 0 & 0 & 0 & 0 & 0 & 0 & 0 & 0 & 0 & 0 & 0 \\
\hline Відвійки св. & 0 & 0 & 0 & 0 & 0 & 0 & 0 & 0 & 0 & 0 & 0 \\
\hline Сироватка.св. & 0 & 0 & 0 & 0 & 0 & 0 & 0 & 0 & 0 & 0 & 0 \\
\hline Мука м.-кіст. & 0 & 0 & 0 & 0 & 0 & 0 & 0 & 0 & 0 & 0 & 0 \\
\hline Разом & 105 & 2,21 & 2,31 & 25,16 & 1653,1 & 286,10 & 227,30 & 83,58 & 11,04 & 3,44 & 8,22 \\
\hline Норма & & & 2,2 & 24,2 & 1900 & 287 & 209 & 125 & 13,3 & 16 & 13 \\
\hline Різниця & 0 & кГ & 0,11 & 0,96 & $-246,8$ & $-0,90$ & 18,30 & $-41,4$ & $-2,26$ & $-12,56$ & $-4,78$ \\
\hline
\end{tabular}

Оскільки всі обчислення здійснюються практично миттєво після задання процентного вмісту і-го корму в стовпчику "Вміст \%", то протягом короткого проміжку часу користувач може знайти таке поєднання кормів в раціоні, при якому відхилення вмісту основних поживних речовин від норми не перевищує допустимих меж i, отже, одержати добре збалансований раціон.

Таблиця 3

Результати обчислень раціону свиней

\begin{tabular}{|c|c|c|c|c|c|c|c|c|}
\hline Вид корму & Вміст (кг) & Вид корму & Вміст (кг) & Параметр & Од. вимір. & Вміст в раціоні & Норма & Різниця \\
\hline Горох & 0,28 & $\begin{array}{l}\text { Картопля } \\
\text { сира }\end{array}$ & 0,37 & $\begin{array}{l}\text { Кормові } \\
\text { одиниці }\end{array}$ & кг & 2,31 & 2,2 & 0,11 \\
\hline Овес & 0 & $\begin{array}{c}\text { Картопля } \\
\text { варена }\end{array}$ & 0 & $\begin{array}{l}\text { Обмінна } \\
\text { енергія }\end{array}$ & Мдж & 25,16 & 24,2 & 0,96 \\
\hline Пшениця & 0,60 & $\begin{array}{c}\text { Буряк } \\
\text { кормовий }\end{array}$ & 0 & $\begin{array}{c}\text { Суха } \\
\text { речовина }\end{array}$ & $\Gamma$ & 1653,11 & 1900 & $-246,89$ \\
\hline Ячмінь & 0,86 & Морква & 0 & Сирий протеїн & $\Gamma$ & 286,10 & 287 & $-0,90$ \\
\hline Кукурудза & 0 & Жом свіжий & 0 & Перетр.протеїн & $\Gamma$ & 227,30 & 209 & 18,30 \\
\hline $\begin{array}{c}\text { Висівки пше- } \\
\text { ничні }\end{array}$ & 0 & Дріжджі сухі & 0 & $\begin{array}{c}\text { Сира } \\
\text { клітковина }\end{array}$ & $\Gamma$ & 83,58 & 125 & $-41,42$ \\
\hline $\begin{array}{c}\text { Макуха со- } \\
\text { няшник. }\end{array}$ & 0,10 & $\begin{array}{l}\text { Молоко } \\
\text { цільне }\end{array}$ & 0 & Лізин & $\Gamma$ & 11,04 & 13,3 & $-2,26$ \\
\hline Вика & 0 & $\begin{array}{c}\text { Відвійки } \\
\text { свіжі }\end{array}$ & 0 & Кальцій & $\Gamma$ & 3,44 & 16 & $-12,56$ \\
\hline Конюшина & 0 & $\begin{array}{c}\text { Сироватка } \\
\text { свіжа }\end{array}$ & 0 & Фосфор & $\Gamma$ & 8,22 & 13 & $-4,78$ \\
\hline Люпин & 0 & $\begin{array}{l}\text { Мука м’ясо- } \\
\text { кісткова }\end{array}$ & 0 & & & & & \\
\hline Люцерна & 0 & Разом & 2,21 & & & & & \\
\hline
\end{tabular}

Закінчивши обчислення, слід перейти до п'ятої сторінки, яка містить таблицю кінцевих результатів розрахунку раціону, що автоматично формується системою на основі розрахункової таблиці (табл. 3). Таблицю п'ятої сторінки можна видрукувати на принтері стандартним для Excel-97 способом. 
Треба мати на увазі, що приклад розрахунку раціону, який наведено в таблицях 1-3, використовується тут лише для пояснення принципу роботи програми. Реально система обчислення раціону годівлі свиней дозволяє балансувати раціон за будь-якою кількістю показників, що містяться в базі даних кормів та в базі норм годівлі тварин. Показники, які не вдається звести до норми кормами, слід балансувати за допомогою відповідних добавок (Polishchuk \& Bulavkina, 2010), кількості яких визначаються від'ємними значеннями стовпчика "Різниця" таблиці 3.

Систему розрахунку раціонів годівлі тварин потрібно доповнити сторінками, за допомогою яких можна обчислити розміри посівних площ кормових культур для годівлі відповідної кількості тварин різних статево-вікових груп. Наприклад, для системи розрахунку раціонів годівлі свиней це буде сторінка 6 - розрахункова таблиця обчислення посівних площ.

Розглянемо послідовність такого розрахунку на основі запропонованого алгоритму (див. рис. 1).

1. Обчислюємо раціони годівлі тварини для різних iï фізіологічних станів, наприклад, для свиноматок - холоста, супоросна, лактуюча, або для різних періодів відгодівлі свиней, наприклад, для маси 30 кг, 60 кг, 90 кг. Результат кожного розрахунку переносимо у відповідний стовпчик сторінки 6 системи.

2. Задаємо тривалість кожного періоду протягом року (в днях або у відсотках від 365 днів у році) - при цьому система автоматично обчислює річну потребу в кормах для однієї тварини.

3. Задаємо кількість тварин, що утримуються протягом року - при цьому система автоматично обчислює річну потребу в кормах для заданої групи тварин.

4. Задаємо середній вихід корму з урожаю для кожної кормової культури, виходячи з досвіду роботи даного господарства, а також коефіцієнти ризику $\left(\mathrm{R}_{\mathrm{i}} \geq 1\right)$, які враховують можливі несприятливі погодні - після цього система автоматично обчислює площі посівів кормових культур.

На цьому закінчується робота зі сторінкою 6 системи. Автоматично формується сторінка, на якій відображаються кінцеві результати обчислень.

\section{References}

Kozii, B., Kravtsiv, R., Kyryliv, Ya., \& Pankiv, I. (2001). Rozrakhunky u tvarynnytstvi zasobamy tablychnoho protsesora Excel. L.: TeRus na zamovlennia "Triadaplius" (in Ukrainian).

Polishchuk, A.A., \& Bulavkina, T.P. (2010). Suchasni kormovi dobavky $\mathrm{v}$ hodivli tvaryn i ptytsi. Visnyk Poltavskoi ahrarnoi akademii, 2, 63-66 (in Ukrainian). Tsereniuk, O.M., Akimov, O.V., \& Kosov, M.O. (2015). Povnotsinna hodivlia svynei. Suchasne tvarynnytstvo, 6(301), 56-58 (in Ukrainian). 